\title{
Geodynamic controls on the distribution of diamondiferous kimberlites
}

\author{
Natapov, L. ${ }^{1}$ and W.L. Griffin, W.L ${ }^{1,2}$ \\ 1 - GEMOC National Key Centre, School of Earth Sciences, Macquarie University, NSW 2109, Australia . \\ 2 - CSIRO Exploration and Mining, P.O. Box 126, North Ryde, NSW 2113, Australia
}

It is well known that kimberlitic diamonds are closely associated with Archaean lithospheric mantle that is rich in low-Ca harzburgite and contains eclogite. In Phanerozoic time, Archean mantle with such properties has been the main locus of diamond-bearing kimberlite magmas. The mechanisms for generating this type of mantle have been discussed for at least 20-30 years. Models involving generation of the mantle peridotite by extraction of komatiites or thick basaltic crust are often proposed to explain this phenomenon; other models invoke the subduction of oceanic lithosphere to explain the high degree of depletion and the low geotherm of Archean mantle. The existence of volcanic rocks of the calc-alkaline series in the basement of ancient continents may be evidence for the existence of these subduction zones in the past.

Many ancient continents are composed of Archean terranes which are sutured by Proterozoic mobile belts, or joined along major shear zones. Comparisons with modern tectonic settings suggest that the nature of the terranes is diverse: continental massifs, magmatic arcs (including island arcs), blocks of oceanic crust. The sizes of Archean terranes varies widely as well. Siberian and North China terranes may have areas on the order of $10^{5} \mathrm{~km}^{2}$, while other terranes may be quite small, as in the Slave Craton (Griffin et al., this vol.). The presence of the favourable ancient mantle mentioned above beneath some terranes must be the main condition controlling the distribution of diamond-bearing kimberlite on ancient platforms.

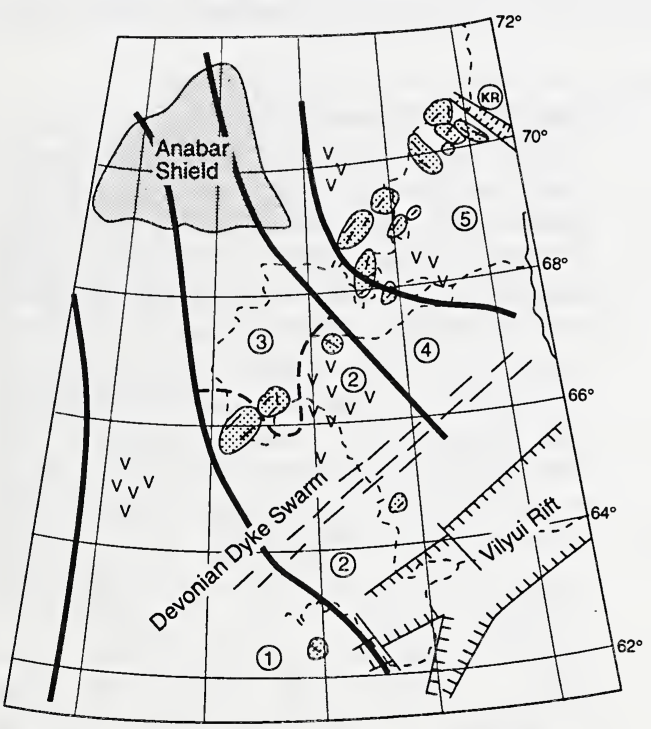

Fig. 1. The Yakutian kimberlite province, with terrane boundaries (thick lines), kimberlite fields with orientation of kimberlite bodies. KR, Kyutungde aulacogen (Devonian). V, calcalkaline volcanics in the basement terranes.
During Phanerozoic time, the eruption of the kimberlite magmas, entrainment of diamonds from the mantle, and rapid ascent of the magmas to the surface were closely related to episodes of lithospheric extension and melting. Two conditions are crucial for the kimberlite to be diamond bearing: (1) kimberlite magmas must originate below, and sample the lithosphere within, the diamond stability field (typically 900 to $1200^{\circ} \mathrm{C}, 40$ to $70 \mathrm{~kb}$ ); (2) eruption of the kimberlite to the surface must be rapid. Only if these two conditions are met will the diamonds captured in the mantle be preserved in the erupting magma.

Kimberlite fields of the same age often form elongated trends. These trends are often accompanied by extension structures such as grabens, dyke swarms, and fault zones. The length of such kimberlite trends can reach 1000 $\mathrm{km}$ (Olenek trend in Siberia, Lucappe corridor of Angola). Kimberlite dykes and the major pipe axes are generally parallel, but sometimes orthogonal, to the trend of the kimberlite field. Alternatively, the kimberlite bodies can cover an isometric area with a diameter of several hundred kilometres. In both cases, the kimberlites can be either diamond-bearing or barren. 


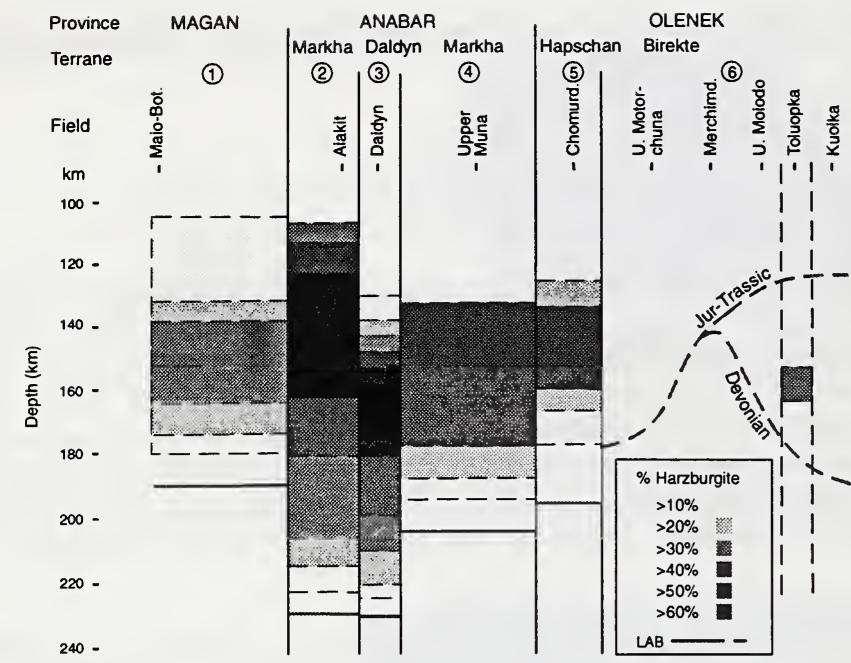

Fig. 2. Lithospheric columns for Siberian terranes, numbered as in Fig. 1, showing vertical distribution of harzburgitic garnets from concentrates.

Many of these features of kimberlite volcanism can be illustrated by the Middle Paleozoic kimberlites of the Yakutian province in Siberia. The ancient Siberian continent consists of a series of Archean and Proterozoic terranes that have a SE-NW strike and are separated by shear zones (Rosen et al, 1994). Metavolcanic rocks of the calc-alkaline series can be recognised among the supracrustal rocks of these terrains. Accretion of these terranes to form the Siberian continent took place in Lower Proterozoic time. In middle Paleozoic time the thickness of the lithosphere varied from terrane to terrane, within the range of 230 to $120 \mathrm{~km}$ (Fig. 2). The Olenek kimberlite trend crosses all these terranes in North Western direction (Fig. 1). From SW to

NE the dominant age of the kimberlites within the trend varies from 360 to $420 \mathrm{My}$. The diamond bearing mantle is located under SW part of the trend. A major swarm of Devonian basaltic dykes parallels the trend to the SE. The Devonian Vilyui rift, farther to the SE, also parallels the kimberlite trend.

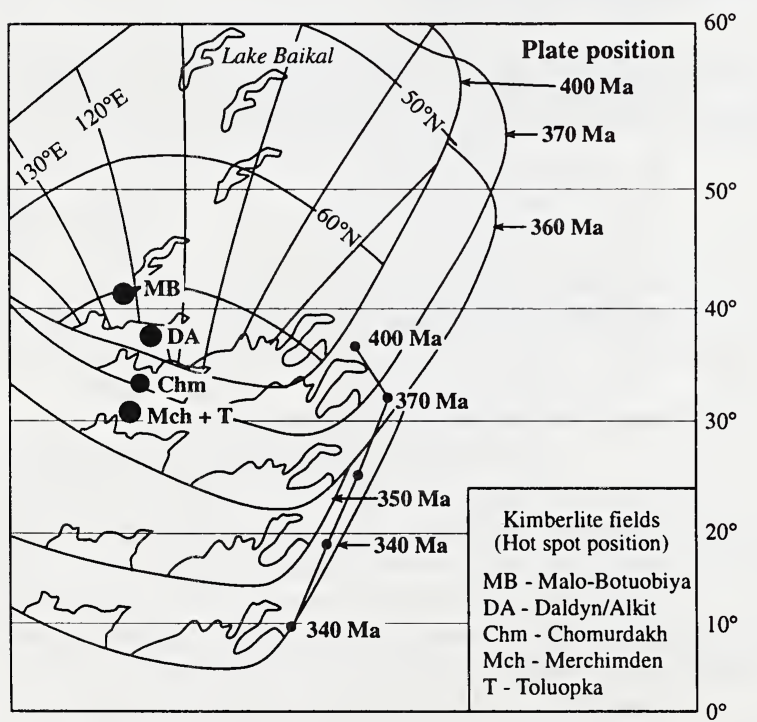

Fig. 2. Palinspastic reconstruction: position of the Siberian plate relative to the Azores hot spot in Devonian time.
Palinspastic reconstructions (Fig. 3) show that the trend appeared when the Siberian plate was passing over a hot spot, which at present is located under the Azore islands. Warming of the mantle and eruption of the kimberlites as well as of the relatively shallow basaltic magmas were caused by the extension of the lithosphere during the process of its movement over the hot spot. The sequence of events related to this extension is as follows. First, the basalt dykes intruded into the crust. The intrusion of the kimberlites was the next stage of the process. The third stage of the extension resulted in the formation of a low-angle detachment fault dipping to the NW. Finally, the Vilyui rift zone developed in the SE part of the detachment. Kimberlites and basalts are located on one side of the Vilyui rift. This can be explained by the orientation of the Wernike detachment zone (Fig. 4) In this particular example, the eruption of basalts and kimberlites, as well as the formation the rift are all interpreted as having been caused by the drift of the plate over the hot spot. 
The presence of diamond in the kimberlites correlates with the thickness (at the time of the kimberlite magmatism), age and composition of the lithosphere under the terranes (Fig.2). Studies of xenoliths and heavy-mineral concentrates (Griffin et al., 1995) show that the thickness of the Archean lithosphere under a diamond bearing kimberlite was typically in the range of 190 to $230 \mathrm{~km}$. Poor kimberlites are usually associated with lithosphere that is 130 to $170 \mathrm{~km}$ thick. This lithosphere may be either Archean or Proterozoic in age. The small thickness of the subcontinental lithospheric mantle beneath the NE part of the Olenek trend is probably caused by thermal erosion, and the replacement of the Archean or Proterozoic lithospheric mantle by younger and less depleted mantle. This process may have been caused by the Upper Proterozoic rifting that led to the development of the Udzha aulacogen.

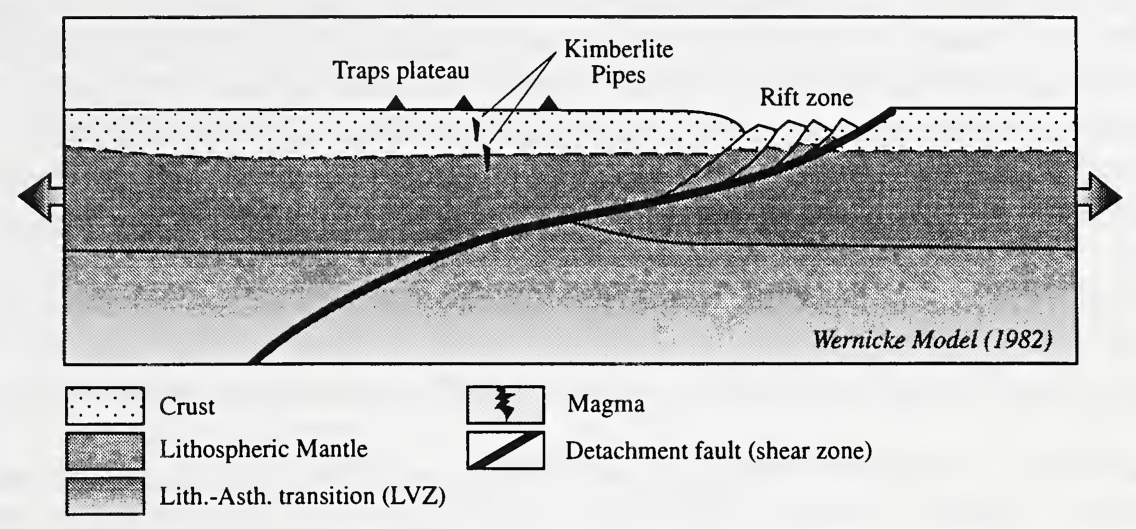

Fig. 4. Detachment model for the linkage between the Vilyui Rift and the Siberian kimberlite province.

The above mentioned features of the spatial distribution of kimberlite are absent when the lithospheric plate is rotating around a hot spot. Nevertheless, the correlation between occurrence of diamondiferous kimberlites and the thickness and composition of the subcontinental lithospheric mantle under different terranes still holds true.

\section{References}

Griffin, W.L., Kaminsky, F., O'Reilly, S.Y., Ryan, C.G. and Sobolev, N.V., 1995, 6th Inter. Kimberlite Conf. Abstracts, 194-195.

Rozen, O.M., Condie, K.C., Natapov, L. and Nozhkin, A., 1994, Developments in Precambrian Geology, 11 , 411-459. 